\title{
Publications scenario about Family Health Support Centers
}

\author{
Cenário de publicações sobre o Núcleo de Apoio à Saúde da Família
}

\begin{tabular}{l} 
AUTHOR'S \\
\hline Thamires Lorenzet Seus $^{1}$ (D) \\
Matheus Pintanel Freitas ${ }^{1}$ (D) \\
Fernando Vinholes Siqueira ${ }^{1}$ ID \\
1 Universidade Federal de Pelotas - Programa de \\
Pós-Graduação em Educação Física, Pelotas, RS \\
- Brasil. \\
CORRE SPONDING \\
Thamires Lorenzet Seus \\
seustl@gmail.com \\
Escola Superior de Educação Física UFPel. \\
Rua Luís de Camões no 625 Três Vendas, \\
Pelotas, RS, Brasil, CEP: $896055-630$ \\
DOI
\end{tabular}

10.12820/rbafs.v.22n5p429-38

\section{(1) $\Theta \Theta$}

Den-access article distributed under the terms of the Creative Commons Attribution License ${ }^{\circledR}$, which permits unrestricted use, distribution, and reproduction in any medium, provided that the original author and source are credited.

\begin{abstract}
A systematic review about publications on the Family Health Support Centers (FHSC) and the participation of the Physical Education Professional (PEP) was conducted. Recorded in PROSPERO, following the recommendations of the Preferred Reporting Items for Systematic Reviews and Meta-Analyses (PRISMA) in Pubmed, Lilacs, Scopus, Bireme and SciELO, with the following keywords: Family Health Support Center; FHSC; Primary Health Care; Health Promotion; Intervention Studies; Physical Education; Physical Activity. Sixty studies about NASF were found, most of them about the implementation of the program and about actions undertaken by the teams. Of the total, seven studies in the area of Physical Education. In conclusion, studies about FHSC are qualitative methods and do not address the effectiveness of the developed actions, only describe them. As well as with publications about PEP.
\end{abstract}

Keywords: Primary Health Care; Health promotion; Physical Education; Training.

RESUMO

Os Núcleos de Apoio à Saúde da Família (NASF) foram criados em 2008 para ampliar a abrangência e as ações das equipes de Saúde da Família. Ainda não há um panorama de estudos sobre o programa e a inserção do Profissional de Educação Física (PEF). O objetivo deste estudo é investigar o cenário de publicações sobre o NASF e a participação do PEF. Conduziu-se revisão sistemática, registrada no PROSPERO, $n^{\circ}$ CRD42016043650, seguindo as recomendações do Preferred ReportingItems for Systematic Reviewsand Meta-Analyses (PRISMA), nas bases de dados Pubmed, Lilacs, Scopus, Biremee SciELO, com as seguintes palavras-chave: Núcleo de Apoio à Saúde da Família; NASF; Atenção Primária à Saúde; Promoção da Saúde; Estudos de Intervenção; Educação Física; Atividade Física; e suas respectivas palavras na língua inglesa. Foram incluídos estudos publicados entre 2008 e 2015. Foram encontrados 60 estudos sobre o NASF, sendo a maioria no método qualitativo, sobre a implantação do programa e ações desenvolvidas pelas equipes.Dentre estes, sete são da área da Educação Física, realizados principalmente na região Sul $(42,8 \%)$. Conclui-se que os estudos sobre o NASF, em sua maioria são de carater qualitativo e não abordam a efetividade das ações desenvolvidas, apenas as descrevem. Bem como acontece com as publicaçôes sobre o PEF.

Palavras-chave: Atenção Primária à Saúde; Promoção da saúde; Educação Física; Treinamento.

\section{Introduction}

Primary care (PC) is the first level of attention of the Brazilian health system ${ }^{1}$ and the main access to the health system. PC is characterized by a set of health actions, in individual and collective scope, which promotion and protection of health, disease prevention, diagnosis, treatment, rehabilitation and maintenance of health. The aim of $\mathrm{PC}$ is to offer universal access and integral care ${ }^{1}$.

Aiming to expand, qualify and consolidate primary care, the National Policy of Primary Care (in portuguese: Política Nacional deAtençãoBásica) gave rise to the Family Health Strategy (FHS) (in portuguese: Estratégia Saúde da Família) ${ }^{1}$. The FHS favors the reorientation of the work process with the possibility to deepen the principles, guidelines and foundations of PC. In addition, it expands the impact on health of the population and provides an important cost-effectiveness relationship ${ }^{1,2}$. Moreover, the FHS replaces the traditional model and improves the quality of life of the population by approaching the families ${ }^{2}$.

The professionals who compose the Family Health teams have general characteristics and, in order to expand the breadth and scope of their actions, in 2008 the Family Health Support Centers (FHSC) (in portuguese: Núcleo de Apoio à Saúde da Família) were created $^{3}$. The FHSC is configured as a multi-professional team that works seamlessly with the Family Health Teams (FHT) (in portuguese: Equipe Saúde 
da Família), primary health care teams (in portuguese: Equipes de Atenção Básica) and with the Community Health and Fitness Program (in portuguese: Programa Academia da Saúde) $)^{2}$.

The Physical Education Professional (PEP), in turn, can be part of the FHSC teams and work together with other professionals in order to promote actions for the prevention and control of chronic diseases and to reduce physical inactivity levels. Even though Brazil has occupied the seventh position amongst the countries that contributed the most in research regarding physical activities in $2013^{4}$ and a thematic edition of the Brazilian Journal of Physical Activity and Health about promotion of physical activity being released in $2016^{5}$, there is still no panorama of the studies on the program and on the inclusion of PEP on FHSC.

Although there is a systematic review in the literature regarding the insertion and performance of $\mathrm{PEP}$ in primary care ${ }^{6}$, no information exclusively related to FHSC is presented and, therefore, there are no data yet on how much the FHSC is searched, or on what types and on which regions of the country the studies are developed. In addition, the increase in the prevalence of Chronic Noncommunicable Diseases (CNCD) signaled the importance of giving attention to the level of physical activity of the populations, since this is an important and modifiable risk factor for such disorders. Furthermore, it is known that if $25 \%$ of world physical inactivity were eliminated, up to 1.3 million deaths per year could be prevented $^{7}$. Globally, physical inactivity is responsible for more deaths per year than smoking ${ }^{8}$, which stresses the importance of this construct in public health.

Faced with this reality, the question is: what is the scenario of publications about the FHSC and how does the participation of the PEP in this context? In order to answer this question, this study aimed to systematic review the literature on the FHSC and to describe the participation of the Physical Education Professional in this multi-professional team. In addition, to characterize them regarding year of publication, study method, sample used, profession involved, and region of Brazil where they took place.

\section{Method}

Study design

A systematic review of the literature on studies involving the FHSC and the Physical Education in the context of publications was performed.

\section{Database and key-words}

The searches were conducted in Pubmed, Lilacs, Scopus, SciELO and Bireme, using the following keywords: Family Health Support Center; FHSC; Primary Health Care; Health Promotion; Intervention Studies; Physical Education; Physical activity and their respective words in Portuguese, Núcleo de Apoio à Saúde da Familia; NASF; AtençãoPrimária à Saúde; Promoção da Saúde; Estudos de Intervenção; Educação Física and Atividade Fisica.

\section{Search strategy}

The review was recorded in the systematic reviews registration base, under registration number CRD42016043650, and follows the recommendations of the Preferred Reporting Items for Systematic Reviews and Meta-Analyses (PRISMA)

Two researchers between December of 2015 and January of 2016 carried out the search independently. Among the combinations, we used the terms Family Health Support Center "OR" FHSC and the operator "AND" to the keywords: 1 - Primary Health Care; 2 Health Promotion; 3 - Intervention Studies; 4 - Physical Education; 5 - Physical Activity; the same method was applied to all these words in Portuguese.

All articles found were exported to the reference management software EndNote, and duplicates were deleted. The references of all papers included in the review were revised with the aim of finding new studies that would fit the inclusion criteria. A full reading of all manuscripts included in this review was accomplished and the information of interest was held. The variables extracted were: year of publication and language, method and type of study, sample, profession involved and region of Brazil where the study took place.

\section{Inclusion and exclusion criteria}

There were no constraints regarding language, year of publication or type of study. The inclusion criteria were: 1) Scientific publication (article, thesis, or dissertation); 2) Presenting the expression "Family Health Support Center" in the title, or "FHSC" in the abstract and other keywords in the text. In the Lilacs database, there was no search option for abstracts only, so in order to search "FHSC", we selected the content "words", considering any text location.

The exclusion of publications occurred 1) when it was not a scientific article, 2) whenthe subject was about the Primary Care (PC) or the Family Health 
Strategy programme (ESF) but without the participation of the Family Health Support Center, 3) when FHSC was not the main theme of the study, 4) in the case of literature review and 5) when the publication was a thesis from which the resulting article arising from it had already been included in the review.

\section{Data analysis}

Data were tabulated in the software Excel for Windows and exported to the Stata statistical package version 12.0 for descriptive analysis.

\section{Results}

Initially, 467 articles were found. Out of these, 291 were duplicates and 98 were excluded for not meeting the specified requirements. Of the 78 articles selected for abstract reading, 26 were excluded. Therefore, 52 papers remained to be part of the study. By reviewing the references of these 52,8 other manuscripts were incorporated, totalizing 60 studies in this review ${ }^{10-13,15-70}$ (Figure 1 ).

Regarding the year of publication, we observed that the first article about the FHSC was published a year after its creation (2009), and in subsequent years (2010 to 2015) one (1.7\%), three (5\%), 13 (21.6\%) 17 (28.3\%) $14(23.3 \%)$ and $11(18.4 \%)$ studies were published, respectively.

From the 60 publications, $95 \%(n=57)$ were in Portuguese. Of the total, 16 were theses or dissertations (all published in Portuguese with English abstract). Amongst the scientific articles $(n=44), 6.8 \%$ were in English ( $n=3)$.

The methodology most commonly used in studies about FHSC is the qualitative approach, which isfound in $81.6 \%$ ( $n=49$ ) of the publications, followed by the quantitative in $16.6 \%$ of the cases $(n=10)$. Only $1.8 \%(n=1)$ used both qualitative and quantitative methodology.

The sample was composed by professional working in Primary Care (FHSC and FHS) in $75.4 \%(n=43)$ of the studies found, followed by the participation of professionals and managers in $8.8 \%(n=5)$, users $5.2 \%(n=3)$, FHSC coordinators in $3.5 \%(n=2)$, managers, professionals and users in 3.5\% ( $\mathrm{n}=2)$. One study interviewed professionals and users (1.8\%) and another one had households as sample units (1.8\%). The sample size of the studies that

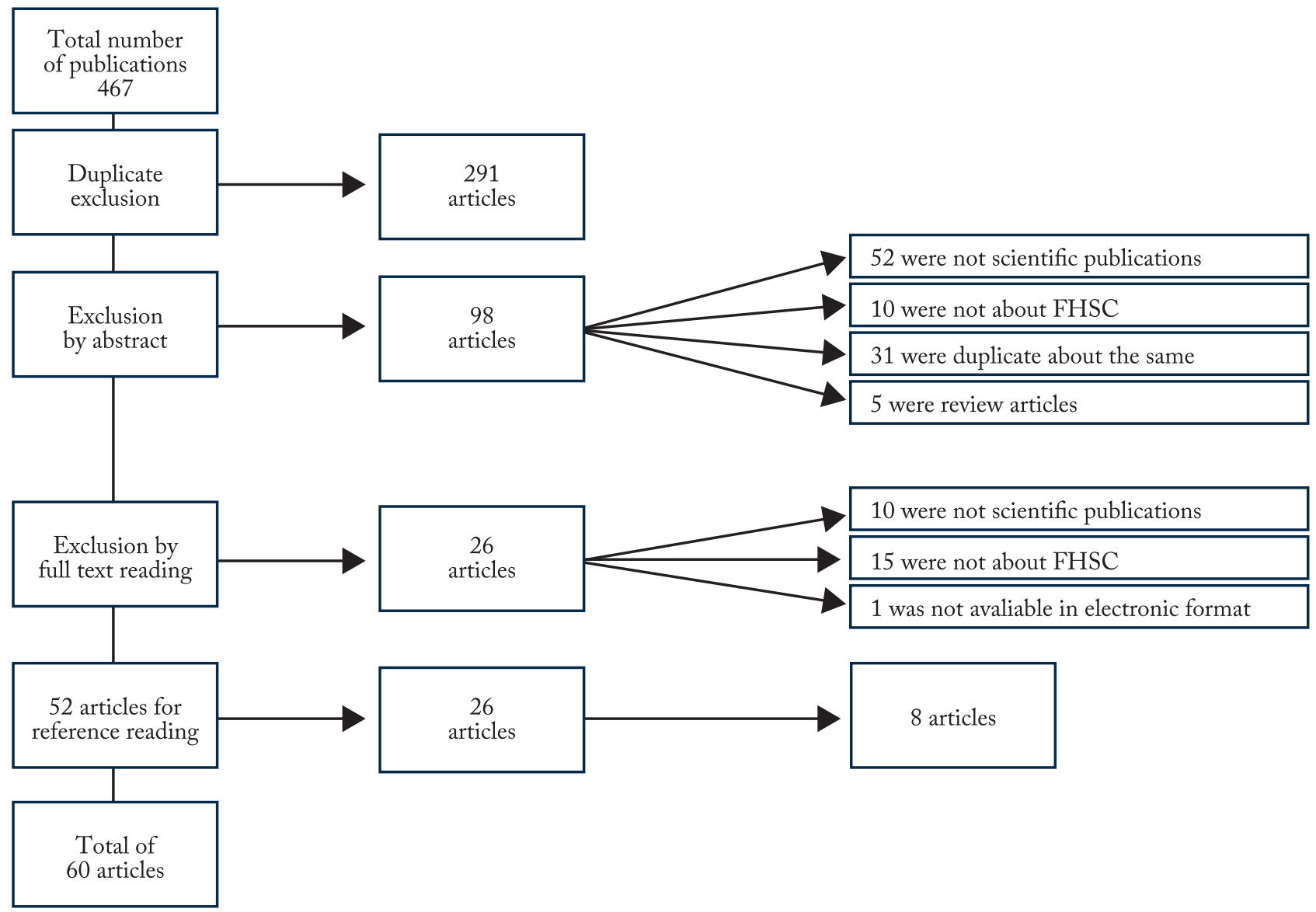

Figure 1 - Flowchart of the search stages of the articles that comprised the review on FHSC. 
were part of this review ranged from $n=1^{10}$ to $n=1251$ individuals ${ }^{11}$. There were those who used secondary data from the Department of Primary Care (DPC) ${ }^{12}$ and from documents of the Ministry of Health ${ }^{13}$.

It can be noted, when addressing the professional field, that most publications (46.7\%) are not specifically related to a profession $(n=28)$. The distribution of publications per field can be observed in Figure 2.

Regarding the regions of Brazil where researches on FHSC were conducted, it was observed that $40 \%$ are from the Northeast $(n=24)$ and $36.7 \%(n=22)$ from the Southeast. 8.3\% $(n=5)$ took place in the Southern region; and $5 \%(n=3)$ in the Midwest. Six studies were carried out covering the whole country (10\%). The states of São Paulo $(n=14)$ and Pernambuco $(n=$

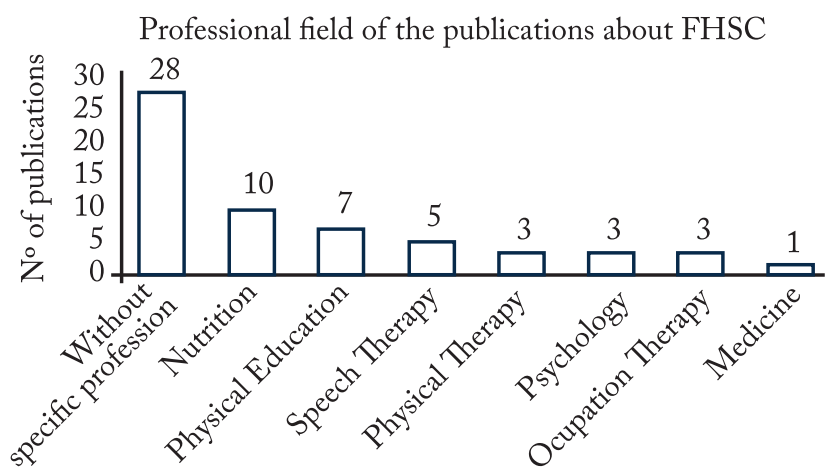

Figure 2 - Distribution of the number of publications about FHSC according to professional field (2009-2015).

7) were most frequently searched with frequency of appearance of $23.3 \%$ and $11.7 \%$, respectively. Figure 3 shows a comparison of the publications in different regions of Brazil and the number of FHSC teams in 2015 according to the Department of Primary Care ${ }^{14}$.

The role of health professionals in the context of FHSC was the subject of $38.4 \%$ of the studies ( $\mathrm{n}=$ 23). Other themes and their prevalence were: implementation of FHSC 8.3\% ( $n=5)$; evaluation of FHSC $8.3 \%(n=5)$; working procedure $8.3 \%(n=5)$; interprofessional relationship $8.3 \%(n=5)$; matrix support $5 \%$ $(n=3)$; evaluation of actions $3.3 \%(n=2)$; professional training $3.3 \%(n=2)$; user satisfaction $3.3 \%(n=2)$; mental health $3.3 \%(n=2)$; food insecurity $1.7 \%(n=$ $1)$; user profile $1.7 \%(n=1)$; professional competences
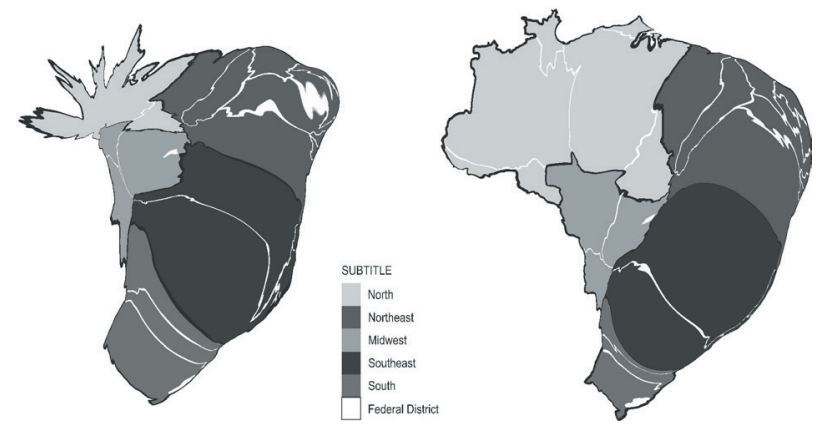

Figure 3 - Density map of number of publications about FHSC (A) and FHSC teams (B) according to the regions of Brazil (2009-2015).

Table 1 - Results of the literature review about Family Health Support Centers with description of method used and study theme.

\begin{tabular}{|c|c|}
\hline Variables & Studies \\
\hline \multirow[b]{2}{*}{ Method of collection and analysis } & Qualitative $(\mathrm{n}=49)^{10,16-31,33-42,45-53,56,57,59-61,63,64,66-70}$ \\
\hline & Quantitative $(\mathrm{n}=10)^{11,12,29,30,31,15,32,33,28,16}$ \\
\hline \multirow{17}{*}{ Theme } & Qualitative and quantitative $(n=1)^{34}$ \\
\hline & Training and professional role $(n=1)^{29}$ \\
\hline & Professional role $(n=23)^{13,35,36,37,38,39,40,41,30,18,42,43,44,33,45,46,16,47,34,48,49,17,50}$ \\
\hline & Profile and professional role $(n=1)^{28}$ \\
\hline & Evaluation of actions $(n=2)^{11,26}$ \\
\hline & FHSC evaluation $(n=5)^{51,52,53,54,55}$ \\
\hline & Interprofessionalrelationship $(\mathrm{n}=5)^{56,57,58,59,60}$ \\
\hline & Matrix support $(n=3)^{61,62,63}$ \\
\hline & Professional training $(n=2)^{64,31}$ \\
\hline & Workprocess $(n=5)^{10,65,66,25,22}$ \\
\hline & Professional competences $(n=1)^{24}$ \\
\hline & Mental health $(n=2)^{67,69}$ \\
\hline & Implementation of FHSC $(n=5)^{10,12,69,70,71}$ \\
\hline & User profile $(n=1)^{15}$ \\
\hline & Work process and matrix support $(n=1)^{72}$ \\
\hline & User satisfaction $(n=2)^{73,74}$ \\
\hline & Food insecurity $(\mathrm{n}=1)^{32}$ \\
\hline
\end{tabular}

FHSC: Family Health Support Centers. 
Table 2 - Results of the literature review on publications about Physical Education in the context of FHSC until the year of 2015. Reference, objective, methodology and results for each study are shown.

\begin{tabular}{|c|c|c|c|}
\hline Reference & Objective & Methodology & Results \\
\hline Souza e $\operatorname{Loch}^{68}$ & $\begin{array}{l}\text { To verify the intervention } \\
\text { characteristics of PEP inserted } \\
\text { in FHSC in northern Paraná } \\
\text { municipalities. }\end{array}$ & $\begin{array}{l}\text { Semi-structured interviews with } \\
\text { seven PEP, interpreted with } \\
\text { elements of the content analysis. }\end{array}$ & $\begin{array}{l}\text { Intervention carried out through specific groups of } \\
\text { physical activities, mini-lectures, home visits, prescription } \\
\text { of aerobic and resisted activities. }\end{array}$ \\
\hline Santos e Benedetti ${ }^{12}$ & $\begin{array}{l}\text { To characterize the } \\
\text { implementation of FHSC and } \\
\text { analyze the insertion of PEP in } \\
\text { Brazil. }\end{array}$ & $\begin{array}{l}\text { Descriptive study with secondary } \\
\text { data from CNES/DATASUS. } \\
\text { Implementation ceiling Indicators } \\
\text { and Expansion Potential (EP) of } \\
\text { FHSC. }\end{array}$ & $\begin{array}{l}\text { The FHSC has great EP. Most municipalities did not } \\
\text { have FHSC implemented. PE inserted in } 49.2 \% \text { of the } \\
\text { teams. }\end{array}$ \\
\hline Loch et al. ${ }^{44}$ & $\begin{array}{l}\text { To verify the profile of users of } \\
\text { the physical activitiy programs } \\
\text { offered by FHSC in Londrina } \\
\text { (PR). }\end{array}$ & $\begin{array}{l}\text { Descriptive and quantitative study. } \\
\text { Interviews with all participants } \\
\text { of physical activities programs } \\
\text { offered in five Primary Health } \\
\text { units }(n=167) \text {. }\end{array}$ & $\begin{array}{l}\text { Participants are mostly female }(89.8 \%) \text {, over } 50 \text { years } \\
\text { old, living close to the sites where the physical activities } \\
\text { take place, with BMI above the normal }(64.6 \%) \text {, good } \\
\text { perceived health }(62.3 \%) \text {, that had participated in the } \\
\text { program two to three times a week }(62.3 \%) \text { and that } \\
\text { move up to class walking }(93.4 \%) \text {. Most participants } \\
\text { claim to have some disease }(78.4 \%) \text {, being hypertension } \\
\text { the most prevalent }(52.7 \%) \text {. }\end{array}$ \\
\hline Gomes et al. ${ }^{11}$ & $\begin{array}{l}\text { To describe the characteristics of } \\
\text { the physical activity programs on } \\
\text { the Primary Care, accordingly to } \\
\text { the presence of FHSC on the city, } \\
\text { and by region in Brazil. }\end{array}$ & $\begin{array}{l}\text { Telephone survey with } 1,251 \\
\text { coordinators of health units. } \\
\text { Questionnaire about the existence } \\
\text { of interventions with physical } \\
\text { activity and ints characteristics. }\end{array}$ & $\begin{array}{l}\text { Health units without FHSC have less physical activity } \\
\text { interventions ( } 32.8 \%) \text { than those whith FHSC }(50 \%) \text {, } \\
\text { p<0.001. Similar interventions in units with and without } \\
\text { FHSC. Mostly walking }(81.8 \%) \text { and stretching }(77.3 \%) \\
\text { groups. Most activities happening in the morning shift } \\
\text { (88\%), once or twice a week ( } 62.5 \%) \text {, with sessions of } 30 \\
\text { minutes to an hour }(51,4 \%) \text {. }\end{array}$ \\
\hline Rodrigues et al..$^{57}$ & $\begin{array}{l}\text { To describe the profile and } \\
\text { role of PEP in FHSC of the } \\
\text { metropolitan region of João } \\
\text { Pessoa, PB. }\end{array}$ & $\begin{array}{l}\text { Semi-structured interviews with } \\
15 \text { PEP that worked for at least } \\
\text { six months on a FHSC. }\end{array}$ & $\begin{array}{l}\text { Licensed professionals in PE. The users perform mainly } \\
\text { stretching }(n=15) \text { and walking }(n=11) \text {. All of them } \\
\text { develop specific evaluations such as blood pressure check } \\
(n=10) \text { and body mass index }(n=10) \text {. All reported actions } \\
\text { directed to hypertension and diabetes. }\end{array}$ \\
\hline Furtado e Knuth ${ }^{36}$ & $\begin{array}{l}\text { To understand, alongside with } \\
\text { the management and with } \\
\text { the PE team, their perception } \\
\text { about the perticular role of the } \\
\text { center and to present elements } \\
\text { about its insertion, barriers, and } \\
\text { contributions on the FHSC and } \\
\text { SUS scenario, on the city of Rio } \\
\text { Grande. }\end{array}$ & $\begin{array}{l}\text { Qualitative research guided by the } \\
\text { theoretical and methodological } \\
\text { Minayo plan. Interviews with } \\
\text { management professional and } \\
\text { PEP from urban FHSC. }\end{array}$ & $\begin{array}{l}\text { FHSC originated from a matricial network of mental } \\
\text { health. The role of the PEP ranges from the clinical } \\
\text { approach until the inclusion and humanization. Health } \\
\text { promotion is the key element to the PEP. Main barrier is } \\
\text { to operate the concept of health promotion in the current } \\
\text { healthcare model. }\end{array}$ \\
\hline Santos et al. ${ }^{61}$ & $\begin{array}{l}\text { To present health education } \\
\text { practices that are developd by } \\
\text { PEP of FHSC in Brazil. }\end{array}$ & $\begin{array}{l}\text { Descriptive and quantitative } \\
\text { study, conducted via telephone } \\
\text { interviews, with a representative } \\
\text { sample of } 296 \text { professionals, } \\
\text { stratified by Brazilian regions and } \\
\text { FHSC modality. }\end{array}$ & $\begin{array}{l}\text { The activities in health education take place in the } \\
\text { Primary Health Care Unit }(89.5 \%) \text { and in open sites } \\
\text { in the community ( } 92.9 \%) \text {. The mais themes addressed } \\
\text { are physical activity, health and quality of life }(51.4 \%) \\
\text { and prevention/treatment of comorbidities }(32.3 \%) \text {. The } \\
\text { users are mostly elderly people }(68.8 \%) \text { and people with } \\
\text { hypertension or diabetes }(30.9 \%) \text {. }\end{array}$ \\
\hline
\end{tabular}

$1.7 \%(\mathrm{n}=1)$; training and professional role 1.7\% $(\mathrm{n}=1)$; work process and matrix support $1.7 \%(\mathrm{n}=1)$; profile and role $1.7 \%(n=1)$. Table 1 shows a summary of all publications about FHSC found in this review.

Regarding articles of the Physical Education field in FHSC ( $n=7)$, mostly used the quantitative method $(n=5)$. Quantitative studies aimed to: a) describe the characteristics of physical activity programs in primary care considering the presence of $\mathrm{FHSC}^{11}$; b) describe the profile of PEP and its performance in $\mathrm{FHSC}^{6}$; c) verify the profile of the users participating in physical activity programs offered by $\mathrm{FHSC}^{15}$; d) characterize the implementation of FHS Cand analyze the insertion of $\mathrm{PEP}^{12}$ and; e) report the Health Education practices developed by PEP in FHSC ${ }^{16}$. Souza and collaborators ${ }^{68}$, through qualitative methodology, sought to verify the intervention characteristics of PEP inserted in FHSC interviewing seven professionals who worked in northern Paraná. In order to understand the insertion of PEP in FHSC, Furtado \& Knuth, using a qualitative methodological strategy, interviewed a management professional and a $\mathrm{PE}$ professional from a FHSC ${ }^{18}$. Table 2 presents a summary of studies of physical education onFHSC. 


\section{Discussion}

The main findingof this review was the predominance of studies about FHSC that describe the professional role $(38.4 \%)$ and $11.7 \%$ with PEP. We summarized the information related to the year of publication, the main subjects addressed, the type of method used in the studies, the regions of Brazil where the researches took place, and the language of the publications.

The FHSC was created by the publication of the Decree No. 154 of the Ministry of Health in 2008 ${ }^{19}$, which explains the fact that the publications about the program start with only a single study in 2009 (1.7\%) with progressive increase in the number of publications until 2013 (28.3\%). In 2014, 23.3\% of the studies were published and in 2015, 18.4\% ( $n=11)$. However, this slight decrease of publications is not relevant if we consider that the number of annual publications on a given subject will not always be constant. For instance, a review that searched for studies on promotion of physical activity in SUS published until April 2015, found that the highest number of publications occurred in the years $2014(n=5)$ and $2013(n=4)$ and no studies were publisehd in $2012^{20}$. In addition, the annual number of FHSC publications may be related to the percentage of teams deployed each year in Brazil. Excluding 2010, when 30\% of the FHSC teams were implanted, 2013 and 2014 were the years that showed greater increase on this number, $18.9 \%$ and $25.5 \%$ respectively, according to the Department of Primary Care ${ }^{21}$.

It was observed that $93.4 \%$ of publications about FHSC are in Portuguese, and even those studies that are published in English, are part of national magazines and were written by authors from Brazilian universities $^{11,22,16}$. This percentage is justified by the fact that the subject is related to a Brazilian health system program, and corroborates with another study that reviews the literature about publications on profissinal actions in primary care ${ }^{6}$, which found that all publications were in Portuguese. Nonetheless, publications in another language promote the Brazilian health model, as seen in a recent review on physical activity promotion in SUS that had $58.8 \%(n=10)$ publications in English $^{20}$. This couldimprove the internationalization of the Brazilian policy related to FHSC, and serve as a model for other government actions all over the planet.

Regarding the largest number of publications with qualitative methodology, Turato $(2005)^{23}$ considers that the qualitative methodology applied to health seeks to understand the individual or collective meaning of a phenomenon to people's lives. By knowing the meanings, it may be possible to improve the quality of professional-patient-family-institution relationship and to promote greater adherence of the population frontto collective measures that are implemented. It can be inferred that the characteristics of the qualitative researches can explain their themes (generally the role of the professionals and the work process) and the use of this method in most publications about FHSC (81.6\%). Whereas its creation was less than eight years ago, the studies seek to describe its implementation and characteristics of the professional role. However, since the FHSC is a public health policy, there is a need for quantitative studies that can be extrapolated and assess the impact that these centers are causing to the population's health and, therefore, evaluate its effectiveness.

About the sample number, it is believed that such variation ( $n=1$ to $n=1,251)$ can be explained by the methodologies used in the studies. In quantitative research, the number of subjects is statistically defined previously and essential to extrapolate the results, while in the qualitative methods this need is not present and the sample size is defined later ${ }^{23}$.

The interviewed subjects were mainly professionals working in primary care $(75.4 \%, n=43)$. We believe that this finding is related to the higher prevalence of the researched theme, namely professional role. This result may also be related to the fact that health care workers are more accessible to be part of such studies.

We also found that of the total number of studies, only 7 describe the participation of the PEP in FHSC (11.7\%). A similar result was found by Rodrigues et al. ${ }^{6}$ in their review article about integration and performance of the physical education professional in primary care. The fact that $46.7 \%$ of the studies about FHSC are not related to a particular profession can be understood by the fact that the studies deal with topics that cover whole teams and not just a single specialty. In addition, the FHSC principles are related to multiprofessional performance and matrix support, where actions are developed with the participation of professionals from different backgrounds prioritizing interdisciplinarity ${ }^{3}$.

We can verify that the prevalence of studies follows, in part, the prevalence of teams by region, with the Southeast region representing the majority of FHSC teams $(28.9 \%)$ and researches $(36.7 \%)$.

Despite the fact that the Southeast region has a higher percentage of publications than FHSC teams, it seems that the number of studies on the FHSC is generally proportional to the number of teams. According to the $\mathrm{PMAQ}^{11}$, in 2015, the distribution of teams in 
Brazil is similar to the publications, namely Northeast for $42 \%$ with the teams, Southeast with $28.9 \%$, South with $14.6 \%$, North with 7.4\%, and Midwest with 7.3\% (Figure 3). One fact to be highlighted is that the North region, despite having the fourth highest prevalence among the regions, does not have specific research. Only studies covering the whole country $(n=6)$ included it ${ }^{11-13,16,24,25}$ which is not the recommendedwhen trying to verify the particularities of a given region. This shows the lack of research in the north of Brazil.

Two studies were subjectively classified as containing the theme "evaluation of actions". One of them qualitatively evaluates aspects related to the structure and process of speech therapist actions in $\mathrm{FHSC}^{26}$. The other one compares the prevalence of physical activity programs according to the presence of FHSC and describes the characteristics of theseactions ${ }^{11}$. However, in this review, no study was identified as to evaluate the effect of interventions on outcomes of interest, presenting results of pre and post evaluation of FHSC interventions in the population. The main theme of the studies found was the description of the work of the health professionals in the context of FHSC.

It can be understood that this finding on the subject of the published works about FHSC may be related to the "stage" in which the FHSC is now. Created eight years ago and with teams implemented since 2010, FHSC is relatively recent if compared with other programs. However, studies evaluating FHSC actions are fundamental for their improvement, what may turn this into the main shortfall to be addressed in future publications.

In general, studies about PEP have similar characteristics to studies on FHSC, i.e., they mainly demonstrate information about the insertion and performance of the PEP in the teams, but do not evaluate the effect of the interventions developed in the outcomes of interest.

Amongst the studies about PE in FHSC, there was a predominance of publications in the South region $(\mathrm{n}=$ 3, 42.8\%). However, Rodrigues and coworkers ${ }^{6}$ have found a predominance of publications in the Southeast. It is believed that these percentages are directly related to the concentration of graduate programs in physical education in these regions and consequently greater number of researchers. These data are strengthened through the research conducted by the Sucupira Platform $^{27}$ in May 2016, which showed that there was 49 functioning graduate courses throughout the country. Of these, $55.1 \%(n=27)$ and $20.4 \%(n=10)$ were in the Southeast and South regions, respectively.

Contrary to the results of the FHSC publications, most studies about physical education used the quantitative method ${ }^{11,12,15,16,28}$, but all of them were observational with a descriptive design. Likewise, the studies with qualitative methodology aimed to describe characteristics of PEP and its interventions in the $\mathrm{FHSC}^{17,18}$. Even though we know that descriptive studies are necessary and indispensable to any new subject in the field of public health, these results demonstrate the lack of diagnostic studies that evaluate the effectiveness of the interventions performed by the PEP, so that the insertion of this professional is legitimized. From the creation of the FHSC with PEP as a possible team member, it is of the utmost importance that researchers using quantitative and qualitative methodologies investigate whether the participation of these professionals has an impact on the different health outcomes of their coverage populations.

Brazil has occupied the seventh position among the countries that contributed the most to publications on physical activity and public health in the world in 2013. However, according to data from the Global Observatory of Physical Activity ${ }^{4}$, the share about FHSC is still small in comparison to the world scene of publications on physical activity. According to the present review, only three studies on $\mathrm{PE}$ in FSHC had been published by 2013 and, according to the Department of Primary Care, up to 2,767 teams were implemented throughout Brazil ${ }^{21}$. However, to date, there are no data on the number of $\mathrm{PE}$ professionals working in the FHSC teams.

These data reinforce the relevance of this review about the FHSC, which included scientific publications on the subject. However, the methodological quality of the included studies was not evaluated, which is a limitation of the present review.

Given the aforementioned findings, it might be observed that the scientific publications about the Family Health Support Center, in most cases, have a qualitative approach concerning the implementation and actions developed by the teams, and on the interprofessional relationships and matrix support. We detected a lack of studies that describe the effectiveness of the actions developed by the teams and the effects of thesuchactions in the population. Regarding the physical education professional, there are only few publications in the literatureand these are aimed towards describing the insertion and role of PEP in FHSC teams. We did not find any publication evaluating neither the effect of the actions of the PEP nor the effect of the interventions on the population's health. 


\section{Conflict of interest}

The authors declared no conflict of interest.

\section{Author's contribuition}

Seus TL and Siqueira FV participated in the search of publi cations, article writing and findings interpretation. Freitas MP participated in the article writing and findings interpretation.

\section{Acknowledgments}

Thanks to Nathalia Gnutzmann for her collaboration in the preparation of the maps.

\section{References}

1. Ministério da Saúde. Política Nacional de Atenção Básica [Internet]. Vol. 5, Série Pactos Pela Saúde. 2006. 60 p. Available from: http://portal.saude.gov.br/portal/arquivos/ pdf/volume_4_completo.pdf.

2. BRASIL. Política Nacional de Atenção Básica [Internet]. Vol. I, Ministério da Saúde. 2012. 110 p. Available from: http://189.28.128.100/dab/docs/publicacoes/geral/pnab.pdf.

3. Ministério da Saúde. Diretrizes do NASF: Núcleo de Apoio a Saúde da Família [Internet]. Cadernos de Atenção Básica. 2010. 152 p. Available from: http://189.28.128.100/dab/ docs/publicacoes/cadernos_ab/abcad27.pdf.

4. Hallal PC. Global Observatory for Physical Activity [Internet]. Physical Activity Country Card: Brazil. 2015 [cited 2016 Dec 27]. Available from: http://www. globalphysicalactivityobservatory.com/.

5. Barros MVG, Lemos EC De, Ramos C, Silva DM. Programs and interventions for physical activity promotion in the Brazilian Unified Health System: a research object that starts to be unveiled.Rev Bras Ativ Fís Saúde. 2016;21(5):385-7.

6. Rodrigues JD, Ferreira DKS, Silva PA, Caminha IO, Farias Junior JC. Inserção e atuação do profissional de educação física na atenção básica à saúde: revisão sistemática. Brazilian Rev Bras Ativ Fis Saúde. 2013;18(1):5-15.

7. Lee I-M, Shiroma EJ, Lobelo F, Puska P, Blair SN, Katzmarzyk PT. Effect of physical inactivity on major noncommunicable diseases worldwide: an analysis of burden of disease and life expectancy. Lancet. 2012;380(9838):219-29.

8. Wen $\mathrm{CP}, \mathrm{Wu} \mathrm{X}$. Stressing harms of physical inactivity to promote exercise. Lancet. 2012;380(9838):192-3.

9. Moher D, Liberati A, Tetzlaff J, Altman DG, The PRISMA Group, A information C and L information. Preferred Reporting Items for Systematic Reviews and Meta-Analyses. PLoS Med. 2009;6(7).

10. Lancman S, Gonçalves RMDA, Cordone NG, Barros JDO. Estudo do trabalho e do trabalhar no Núcleo de Apoio à Saúde da Família. Rev Saude Publica. 2013;47(5):968-75.

11. Gomes GAO, Kokubun E, Mieke GI, Ramos LR, Pratt M, Parra DC, et al. Characteristics of physical activity programs in the Brazilian primary health care system. Cad Saude Publica. 2014;30(10):2155-68.

12. Santos SFS, Benedetti TRB. Cenário de implantação do Núcleo de Apoio a Saúde da Família e a inserção do profissional de Educação Física. Rev Bras Ativi Fís Saúde. 2012;17(3):188-94.

13. Vasconcelos IAL, Sousa MF, Santos LMP. Evolução do quantitativo de nutricionistas na Atenção Básica do Brasil: A contribuição dos Núcleos de Apoio à Saúde da Família e da Estratégia Saúde da Famíla de 2007 a 2013. Rev Nutr. 2015;28(4):431-50.
14. Departamento de Atenção Básica. Relatório Estadual de Equipes de NASF [Internet]. Relatório Estadual de Equipes de NASF. 2016 [cited 2016 Apr 16]. Available from: http:// dabsistemas.saude.gov.br/sistemas/pmaq_relatorio/relatorio/ adesaopmaq.

15. Aguiar CB, Costa NMSC. Formação e atualização de nutricionistas dos Núcleos de Apoio à Saúde da Família. Rev Nutr. 2015;28(2):207-16.

16. Ambrósio CES, Lorentz DL, Santos GFV, Leal LCDL, Nery TN. Atuação dos profissionais dos Núcleos de Apoio a Saúde da Família (NASF) com enfoque ao trabalho do nutricionista. Vol. 1. UNIVERSIDADE VALE DO RIO DOCE; 2009. Available from: https://slidex.tips/download/ universidade-vale-do-rio-doce-univale-faculdade-deciencias-da-saude-facs-curso.

17. Andrade AF, Lima MM, Silva NPMVL. Avaliação das ações da Fonoaudiologia no NASF da cidade do Recife. Audiol Commun Res. 2014;19(1):52-60.

18. Andrade LMB, Quandt FL, Campos DA, Delziovo CR, Coelho EBS, Moretti-Pires RO. Análise da implantação dos Núcleos de Apoio à Saúde da Família no interior de Santa Catarina. Sau \&Transf Soc. 2012;3(1):18-31.

19. Araújo EMD, Galimbertti PA. A colaboração interprofissional na estratégia saúde da família. Psicol Soc [Internet]. 2013;25(2):461-8. Available from: http:// www.scielo.br/scielo.php?script=sci_arttext\&pid=S010271822013000200023\&lng=pt\&nrm=iso\&tlng=pt.

20. Silva N, Kind L. Psicologia nos Núcleos de Apoio à Saúde da Família em Belo Horizonte. Psicol Ciência e Profissão. 2013;33(3):520-35.

21. Barros JDO, Gonçalves RMDA, Kaltner RP, Lancman S. Estratégia do apoio matricial: a experiência de duas equipes do Núcleo de Apoio à Saúde da Família (NASF) da cidade de São Paulo, Brasil. Cien Saude Colet. 2015;20(9):2847-56.

22. Barros CML, Farias Junior G. Avaliação da atuação do nutricionista nos Núcleos de Apoio à Saúde da Família (NASF) do município de Picos/PI. Rev Saúde e Desenvolv. 2012;1(1):140-54.

23. Bezerra PA. Atuação dos profissionais do Núcleo de Apoio à Saúde da Família no Recife: desafios e possibilidades [Internet]. Centro de Pesquisas Aggeu Magalhães; 2013. Available from: http://arca.icict.fiocruz.br/handle/ icict/12258.

24. Bezerra RSS, Carvalho MFS, Silva TPB, Silva FO, Nascimento CMB, Mendonça SS, et al. Arranjo matricial e o desafio da interdisciplinaridade na atenção básica: a experiência do Nasf em Camaragibe/PE. Divulg Saúde Debate. 2010;49:51-9.

25. Bonaldi AP, Ribeiro MD. Núcleo de Apoio à Saúde da Família: as ações de promoção da saúde no cenário da estratégia Sáude da Família. Rev APS. 2014;17(2):195-203.

26. Brito FRSS. Os nutricionistas do Núcleo de Apoio à Saúde da Família (NASF) do município do Rio de Janeiro: perfil, formação profissional e prática [Internet]. Escola Nacional de Saúde Pública Sergio Arouca; 2015. Available from: http:// arca.icict.fiocruz.br/handle/icict/12970.

27. Cela M, Oliveira IF. O psicólogo no Núcleo de Apoio à saúde da Família: articulação de saberes e ações. Estud Psicol. 2015;20(1):31-9.

28. Costa JP, Jorge MSB, Vasconcelos MGF, Paula ML, Bezerra IC. Resolubilidade do cuidado na atenção primária: articulação multiprofissional e rede de serviços. Saúde Debate. 2014;38(103):733-43.

29. Costa LS, Alcântara LM, Alves RS, Lopes AMC, Silva AO, Sá LD. A prática do fonoaudiólogo nos Núcleos de Apoio à Saúde da Família em municípios paraibanos. CoDAS. 2013;25(4):381-7. 
30. Dibai Filho AV, Aveiro MC. Atuação Dos Fisioterapeutas Dos Núcleos De Apoio À Saúde Da Família Entre Idosos Do Município De Arapiraca-Al, Brasil. Rev Bras Promoç Saude. 2012;25(4):397-404.

31. Farias PB. Atuação do nutricionista em equipe multiprofissional na atenção básica de saúde. 2012;129. Available from: http://pesquisa.bvsalud.org/portal/resource/ pt/lil-713177.

32. Fernandes TL, Nascimento CMB, Sousa FOS. Análise das atribuições dos fonoaudiólogos do NASF em municipio da região metropolitana do Recife. Rev CEFAC. 2013;15(1):153-9.

33. Ferro LF,Silva EC, Zimmermann AB, Titotto Castanharo RC, Oliveira FRL. Interdisciplinaridade e intersetorialidade na estratégia saúde da família e no núcleo de apoio à saúde da família: Potencialidades e desafios. Mundo da Saúde. 2014;38(2):129-38.

34. Fittipaldi ALM. Apoio Matricial nas ações de Alimentação e Nutrição: visão dos profissionais da Estratégia de Saúde da Família de Manguinhos, Rio de Janeiro, RJ [Internet]. Escola Nacional de Saúde Pública Sergio Arouca; 2013. Available from: http://157.86.8.70:8080/certifica/bitstream/ icict/2314/2/0000111.pdf\%5Cnhttp://bvssp.icict.fiocruz.br/ lildbi/docsonline/get.php?id=3721.

35. Fragelli TBO. Análise das Competências Profissionais no Núcleo de Apoio à Saúde da Família. Universidade de Brasília; 2013. Available from: http://repositorio.unb.br/ handle/10482/14451.

36. Furtado G, Knuth AG. Núcleo de Apoio à Saúde da Família (NASF) em Rio Grande/RS: percepções sobre o trabalho realizado pela educação física. Rev Bras Atividade Física Saúde. 2015;20(5):514-23.

37. Gomes LMD. O Núcleo de Apoio à Saúde da Família (NASF) e a integralidade na atenção básica em saúde mental em um Município da região serrana do Rio de Janeiro. 2013;82. Available from: http://bvssp.icict.fiocruz.br/lildbi/ docsonline/get.php?id=3838.

38. Gonçalves RMDA, Lancman S, Sznelwar LI, Cordone NG, Barros JDO. Estudo do trabalho em Núcleos de Apoio à Saúde da Família (NASF), São Paulo,Brasil. Rev Bras Saúde Ocup. 2015;40(131):59-74.

39. Hori AA, Nascimento A de F. O Projeto Terapêutico Singular e as práticas de saúde mental nos Núcleos de Apoio à Saúde da Família (NASF) em Guarulhos (SP), Brasil. Cien Saude Colet. 2014;19(8):3561-71.

40. Lancman S, Barros JDO. Estratégia de saúde da família (ESF), Núcleo de Apoio à Saúde da Família (NASF) e terapia ocupacional: problematizando as inerfaces. Rev Ter Ocup Univ São Paulo. 2011;22(3):263-9.

41. Leite DC, Andrade AB, Bosi MLM. A inserção da Psicologia nos Núcleos De Apoio À Saúde Da Família. Physis Rev Saúde Coletiva. 2013;23(4):1167-87.

42. Leite DF, Nascimento DDG do, Oliveira MA de C. Qualidade de vida no trabalho de profissionais do NASF no município de São Paulo. Physis Rev Saúde Coletiva. 2014;24(2):507-25.

43. Lima ACS, Falcão IV. A formação do terapeuta ocupacional e seu papel no Núcleo de Apoio à Saúde da Família - NASF do Recife, PE. Cad Ter Ocup [Internet]. 2014;7(1):3-14. Available from: http://dx.doi.org/10.4322/cto.2014.002.

44. Loch MR, Teixeira DC, Rodrigues CG. E Os Homens? E Os Que Moram Longe ? E Os Mais Jovens? Perfil Dos Usuários De Programas De. Rev Bras Ciências do Esporte [Internet]. 2013;35(4):947-61.
45. Mafra LPV. A trajetória do NASF no município de Piraí: uma análise para além da gestão. Universidade do Estado do Rio de Janeiro; 2012. Available from: http://pesquisa.bvsalud. org/cvsp/resource/pt/lil-653037?lang=pt.

46. Magalhães CCB. Contribuição dos Núcleos de Apoio à Saúde da Família (Nasf) para o desenvolvimento de ações de Saúde do Trabalhador. Vol. 1, Dissertação (Mestrado) - Escola Nacional de Saúde Pública Sergio Arouca. 2014. Available from: https://www.arca.fiocruz.br/handle/icict/1420647.

47. Menezes CADE. Implantação do núcleo de apoio ao programa de saúde da família (NASF) em Olinda: Estudo de Caso. Dissertação (Mestrado) 2011. Available from: http:// www.cpqam.fiocruz.br/bibpdf/2011menezes-ca.pdf.

48. Molini-avejonas DR, Aboboreira MS, Inês M, Couto V, Molini-avejonas DR. Inserção e atuação da Fonoaudiologia nos Núcleos de Apoio à Saúde da Família. 2014;26(2):148-54.

49. Nascimento CMB. Núcleo de Apoio à Saúde da Família: uma análise da atenção à saúde em municípios da Região Metropolitana do Recife [Internet]. Fundação Oswaldo Cruz; 2014. Available from: http://arca.icict.fiocruz.br/ handle/icict/10666.

50. Nóbrega JSM. Avaliação das ações do Núcleo de Apoio à Saúde da Família (NASF) em Macaíba/RN. Vol. 1. Universidade Federal do Rio Grande do Norte. Dissertação (Mestrado) 2013. Available from: https://repositorio.ufrn.br/ jspui/handle/123456789/17827.

51. Oliveira FRL. A integração das ações no campo da Saúde Mental entre a Estratégia de Saúde da Família e o Núcleo de Apoio à Saúde da Família: desafios para uma prática interdisciplinar. Instituto de Psicologia da Universidade de São Paulo 2013.

52. Patrocínio SSSM. Núcleo de Apoio à Saúde da Família: proposta nacional e a implementação em municípios do estado do Rio de Janeiro. Fundação Oswaldo Cruz. Dissertação (Mestrado) 2012. Available from: https://www. arca.fiocruz.br/bitstream/icict/24618/1/677.pdf.

53. Peixoto MRG, Ramos K, Martins KA, Schincaglia RM, Silva LAB. Insegurança alimentar na área de abrangência do Núcleo de Apoio à Saúde da Família em Itumbiara, Goiás. Epidemiol e Serviços Saúde. 2014;23(2):327-36.

54. Reis DCD, Flisch TMP, Vieira MHF, Santos-Junior WS. Perfil de atendimento de um Núcleo de Apoio à Saúde da Família na área de reabilitação, Município de Belo Horizonte, Estado de Minas Gerais, Brasil, 2009. Epidemiol e Serviços Saúde. 2012;21(4):663-74.

55. Reis F, Vieira ACVC.Perspectivas dos terapeutas ocupacionais sobre sua inserção nos Núcleos de Apoio à Saúde da Família (NASF) de Fortaleza, CE Insertion of occupational therapists in the support centers for family health of Fortaleza. Cad Ter Ocup. 2013;21(2):351-60.

56. Rodrigues DCM, Bosi MLM. O lugar do nutricionista nos Núcleos de Apoio à Saúde da Família. Rev Nutr. 2014;27(6):735-46.

57. Rodrigues JD, Ferreira DKS, Junior JCF, Caminha IO, Florindo AA, Loch MR. Perfil e atuação do Profissional de Educação Física nos Núcleos de Apoio à Saúde da Família na região metropolitana de João Pessoa, PB Profile and conduct of Physical Education Professionals in health family teams of the metropolitan region in João Pesso. Rev Bras Atividade Física Saúde. 2015;20(4):352-65.

58. Sampaio J. O NASF como dispositivo da gestão: limites e possibilidades. Rev Bras Ciências da Saúde. 2012;16(3):317-4. 
59. Sampaio J, Martiniano C, Rocha A, Neto A, Sobrinho G, Marcolino E, et al. Núcleo de Apoio à Saúde da Família: Refletindo sobre as Acepções Emergentes da Prática. Rev Bras Ciências da Saúde. 2013;17(1):47-54.

60. Santana JS, Azevedo TL, Reichert ADS, Medeiros AL, Soares MJGO. Center for family health support: team performance at the family health strategy. Rev Pesqui Cuid é Fundam Online. 2015;7(2):2362.

61. Santos SFS, Benedetti TRB, Medeiros TF, Freitas CLR, Sousa TF, Costa JLR. The work of physical education professionals in Family Health Support Centers (NASF): a national survey. Rev Bras Cineantropom Desemp Hum. 2015:693-704.

62. Silva ATC, Aguiar ME, Winck K, Rodrigues KGW, Sato ME, Grisi SJFE, et al. Núcleos de Apoio à Saúde da Família: desafios e potencialidades na visão dos profissionais da Atenção Primária do Município de São Paulo, Brasil. Cad Saude Publica. 2012;28(11):2076-84.

63. Silva JP. A inserção do nutricionista no NASF no município do Rio de Janeiro. 2012.

64. Soleman C, Martins CL. O trabalho do fonoaudiólogo no Núcleo de Apoio à Saúde da Família (NASF) - Especifidades do trabalho em equipe na Atenção Básica. Rev CEFAC. 2015;17(4):1241-53.

65. Souza FLD, Chacur EP, Rabelo MRG, Silva LAM, Villela WV. Implantação do Núcleo de Apoio à Saúde da Família : percepção do usuário. Saúde em Debate. 2013;37(97):233-40.

66. Souza MC, Bomfim AS, Souza JN, Vilela ABA, Franco TB. Fisioterapia e Núcleo de Apoio à Saúde da Família: um estudo sob a ótica dos gestores, profissionais e usuários de saúde da família. Rev APS. 2014;17(2):189-4.

67. Souza MC, Bomfim AS, Souza JN, Franco TB. Fisioterapia e Núcleo de Apoio à Saúde da Família: conhecimento, ferramentas e desafios. O Mundo da Saúde. 2013;37(2):176-84.
68. Souza SC, Loch MR. Intervenção do profissional de educação física nos Núcleos de Apoio à Saúde da Família em municípios do norte do Paraná. Rev Bras Ativi Fís Saúde. 2011;16(1):5-10.

69. Vannucchi AMC, Junior NC. Modelos tecnoassistenciais e atuação do psiquiatra no campo da atenção primária à saúde no contexto atual do Sitema Único de Saúde, Brasil. Physis Rev Saúde Coletiva. 2012;22(3):963-82.

70. Ministério da Saúde. Portaria 154/2008. Núcleos de Apoio à Saúde da Família. Disponível em: <http://bvsms.saude.gov.br/ bvs/saudelegis/gm/2008/prt0154_24_01_2008.html>. Acesso em: 12 dez. 2015.

71. Becker LA, Gonçalves PB, Reis RS. Programas de promoção da atividade física no Sistema Único de Saúde brasileiro : revisão sistemática. Rev Bras Ativi Fís Saúde. 2016;21(1):112-24.

72. Departamento de Atenção Básica. Histórico de Cobertura da Saúde da Família [Internet]. Teto, credenciamento e implantação das estratégias de Agentes Comunitários de Saúde, Saúde da Família e Saúde Bucal. 2016. Available from: http://dab.saude.gov.br/portaldab/historico_cobertura_ sf.php.

73. Turato ER. Métodos qualitativos e quantitativos na área da saúde: Definições, diferenças e seus objetos de pesquisa. Rev Saude Publica. 2005;39(3):507-14.

74. CAPES. Plataforma Sucupira [Internet]. Dados Cadastrais do Programa. 2016 [cited 2016 May 10]. Available from: https://sucupira.capes.gov.br/sucupira/.

Recebido: 10/09/2017

Aprovado: 12/12/2017

Quote this article as:

Seus TL, Freitas MP, Siqueiras FV. Publications scenario about Family Health Support Centers. Rev Bras Ativ Fis Saúde. 2017; 22(5):429-38. DOI: 10.12820/rbafs. v.22n5p429-38. 